\title{
FORMULASI DAN PENGOLAHAN MARGARIN MENGGUNAKAN FRAKSI MINYAK SAWIT PADA SKALA INDUSTRI KECIL SERTA APLIKASINYA DALAM PEMBUATAN BOLU GULUNG
}

\author{
Formulation and Production of Margarine Using Palm Oil Fractions in Small-Scale Industry and Its Application \\ in Roll Cake
}

Hasrul Abdi Hasibuan, Aga Prima Hardika

Pusat Penelitian Kelapa Sawit, Jl. Brigjend Katamso No. 51, Medan 20158

Email: hasibuan_abdi@yahoo.com

\begin{abstract}
ABSTRAK
Pengembangan produk bakery memberikan dampak positif terhadap peningkatan konsumsi margarin. Selain itu, variasi formula margarin semakin diperlukan untuk pengembangan produk bakery yang beragam, dengan demikian produksi margarin cukup menjanjikan untuk dikembangkan pada skala industri kecil dan menengah (IKM). Penelitian ini bertujuan untuk membuat margarin dengan menggunakan minyak sawit (refined bleached deodorized palm oil, RBDPO) dan minyak sawit merah (red palm oil, RPO) serta aplikasinya dalam pembuatan bolu gulung. RPO digunakan sebagai pewarna alami dan pro-vitamin A, sehingga tidak perlu lagi menambahkan pewarna dan vitamin pada margarin. Penelitian ini dilakukan dengan 3 tahapan meliputi: 1) formulasi margarin dengan mencampurkan antara RBDPO dan RPO pada rasio 97,5:2,5 - 85:15 melalui pendekatan sifat fisika kimia margarin komersial meliputi komposisi asam lemak, bilangan iod, titik leleh dan kandungan lemak padat, 2) optimasi produksi margarin menggunakan formula terbaik dari kegiatan 1 pada reaktor texturing skala $50 \mathrm{~kg} /$ batch dengan memvariasikan suhu media pendingin $(5 \pm 2$, $\left.12 \pm 2,20 \pm 2{ }^{\circ} \mathrm{C}\right)$ dan waktu proses $(0,30,45,60,90,120$ menit). Produk dianalisis kadar air, warna, bentuk, tekstur dan stabilitasnya selama penyimpanan, dan 3) aplikasi margarin dalam pembuatan bolu gulung dan uji organoleptiknya. Hasil pengembangan formulasi margarin menggunakan RBDPO dan RPO diperoleh formula yang setara dengan margarin pembanding pada rasio 95:5. Kondisi optimum proses skala $50 \mathrm{~kg} / \mathrm{batch}$ yang menghasilkan margarin dengan tekstur dan stabilitas terbaik diperoleh pada suhu pendingin $5 \pm 2{ }^{\circ} \mathrm{C}$ atau $12 \pm 2{ }^{\circ} \mathrm{C}$ selama 30 menit. Aplikasinya pada bolu gulung menunjukkan bahwa margarin ini relatif baik dengan pengembangan bolu lebih tinggi $0,2 \mathrm{~cm}$ dibandingkan margarin pembanding. Hasil uji organoleptik bolu gulung menggunakan margarin ini memberikan tingkat kesukaan terhadap rasa, tekstur dan kenampakan tidak berbeda nyata dengan margarin pembanding. Dengan demikian, margarin yang dibuat dari RBDPO dan RPO pada penelitian ini memiliki kualitas memadai dan setara dengan produk komersial.
\end{abstract}

Kata kunci: Formulasi, minyak sawit, minyak sawit merah, texturisasi, lemak plastis

\begin{abstract}
The development of bakery products has a positive impact on increasing margarine consumption. In addition, the variations of margarine formula are increasingly required for the development of the variety of bakery products, thus the production of margarine is promising to be developed on the small industries. The aims of the research was to produce margarine using palm oil and red palm oil and its application in roll cake. RPO was added in mixture as natural dyes and pro-vitamine A, so no need to use synthetic dyes. This research was conducted with 3 stages include: 1) formulation of margarine with mixing RBDPO and RPO at ratio 97.5:2.5 to 85:15 through the chemical physical properties approach of commercial margarine include fatty acid composition, iodine value, melting point and solid fat content, 2) optimization of the production of margarine using the best formula in reactor for texturing at $50 \mathrm{~kg} /$ batch with varying temperature of the cooling medium $\left(5 \pm 2,12 \pm 2,20 \pm 2{ }^{\circ} \mathrm{C}\right)$ and the time of process $(0,30,45,60$, $90,120 \mathrm{~min})$. Product was analyzed include water content, color, form, texture and their stability during storage, and 3) application of margarine for preparation of roll cake and its organoleptic test. Formulation of margarine using RBDPO and RPO resulted in equivalent formula with the commercial margarine at the ratio 95:5. The optimum process condition for production of margarine at $50 \mathrm{~kg} / \mathrm{bacth}$ with the best texture was obtained at cooler temperature $5 \pm 2{ }^{\circ} \mathrm{C}$ or
\end{abstract}


$12 \pm 2{ }^{\circ} \mathrm{C}$ for 30 minutes. The application of margarine in roll cake indicated that margarine obtained from this research resulted in expansion which is $0.2 \mathrm{~cm}$ higher than the commercial margarine. The results of organoleptic test of roll cake using margarine obtained from this study showed that the level of preference for the taste, texture and appearance were not significantly different compared to the commercial margarine. Thus, margarine made from RBDPO and RPO in this study had adequate quality and comparable to commercial products.

Keywords: Formulation, palm oil, red palm oil, texturisation, plastic fat

\section{PENDAHULUAN}

Margarin adalah produk makanan berbentuk plastis yang merupakan emulsi air dalam lemak. Margarin banyak dimanfaatkan dalam pembuatan produk bakery seperti bolu, roti, dan lain-lain, serta sering juga digunakan sebagai media penggoreng. Margarin merupakan campuran antara 80\% lemak dan 15-16\% air, serta bahan lain berupa garam, flavor, pengemulsi, pewarna, vitamin dan lain-lain (Noraini dan Teah, 1994; Hui, 1996; O’brien, 2004; Hasibuan, 2009; Sahri dan Idris, 2010).

Awalnya, margarin dibuat dari lemak hewani namun kemudian beralih ke minyak nabati yang telah mengalami hidrogenasi. Minyak/lemak terhidrogenasi telah diketahui mengandung asam lemak trans (ALT) yang berbahaya bagi kesehatan (Berger dan Idris, 2005). Beberapa peneliti telah melaporkan kandungan ALT pada margarin. Ovesen dkk. (1996) melaporkan kandungan ALT pada margarin danish sebesar 4,2 $\pm 2,8 \%$. Larque dkk. (2003) melaporkan margarin di Spanyol mengandung ALT sebesar 5 \%. Sughara dkk. 2006 melaporkan ALT pada margarin lokal yang beredar di Jepang sebesar 2,9-22,4\%. Butt dan Sultan (2009) melaporkan kadar ALT pada margarin yang beredar di Argentina sebesar 18,1531,84\%. Naz dkk. (2012) melaporkan ALT pada margarin yang beredar di Pakistan sebesar 1,56-23,99\%. Siahaan dan Sinaga (2014) melaporkan dua dari delapan sampel margarin yang beredar di Indonesia mengandung ALT sebesar 0,11$0,5 \%$.

Upaya untuk menghindari adanya ALT pada margarin dapat dilakukan dengan menggunakan alternatif proses lain meliputi interesterifikasi dan pencampuran (blending) antara minyak berbentuk cair, semi padat dan padat (Hui, 1996; Berger dan Idris, 2005; O’brien, 2004). Salah satu jenis minyak tanpa proses hidrogenasi yang berbentuk semi padat adalah minyak sawit bahkan fraksi stearinnya berbentuk padat (Hasibuan dkk., 2009). Minyak sawit memiliki kandungan lemak padat yang sangat sesuai untuk margarin (Lumor dan Akoh, 2005).

Pembuatan margarin dilakukan dengan cara membuat emulsi antara fase minyak dengan fase air menggunakan pengemulsi. Tahapan prosesnya meliputi formulasi lemak/ minyak, pencampuran fase minyak dengan fase air, pendinginan untuk pembentukan plastisasi atau teksturisasi dan tempering (Noraini dan Teah, 1994; Hasibuan, 2009).

Produsen margarin di Indonesia umumnya menggunakan refined bleached deodorized palm oil (RBDPO) dan refined bleached deodorized palm stearin (RBDPS) menggunakan teknik blending karena prosesnya sederhana dan biayanya relatif murah. Bahan tambahan lain yang sering digunakan adalah pewarna dan vitamin A danE yang ketersediaannya masih diimpor dari luar negeri. Salah satu fraksi minyak sawit yang mengandung karoten (sebagai pro-vitamin A), tokoferol dan tokotrienol (vitamin E) dan berwarna kemerahan adalah minyak sawit merah (red palm oil, RPO) (Rice dan Burns, 2010; Ayeleso dkk., 2012). Dengan demikian, pemanfaatan RPO dalam formulasi margarin dapat meminimalisir bahkan meniadakan penambahan pewarna, vitamin A dan vitamin E sintetik (Jatmika, 1997). Oleh sebab itu, penelitian ini dilakukan untuk membuat margarin berbahan RBDPO dan RPO (sebagai pemberi warna, pro-vitamin A dan E), serta mengaplikasikannya dalam pembuatan produk bakery berupa bolu gulung.

\section{METODE PENELITIAN}

\section{Material}

Lemak yang digunakan pada penelitian ini adalah refined bleached deodorized palm oil (RBDPO) diperoleh dari PT. Multimas Nabati Indonesia, Wilmar Internasional Group di Kuala Tanjung, Sumatera Utara dan red palm oil (RPO) diperoleh dari Laboratorium Oleopangan Kelompok Peneliti Pengolahan Hasil dan Mutu, Pusat Penelitian Kelapa Sawit di Medan. Bahan-bahan untuk margarin meliputi garam, flavor, lesitin, BHA dan BHT diperoleh dari toko bahan kue di Medan. Bahan-bahan untuk bolu gulung meliputi tepung, telur, gula diperoleh dari toko bahan kue di Medan. Bahanbahan kimia untuk analisis seperti: heksan, triflorobromida, natrium klorida, dan etanol diperoleh dari pemasok lokal $E$. Merck.

\section{Alat}

Reaktor texturing adalah alat untuk membuat margarin pada skala $50 \mathrm{~kg} /$ batch terbuat dari stainless 
steel dan dilengkapi dengan panel listrik untuk pengaturan suhu pendingin, sirkulasi air dan minyak serta kecepatan pengadukan. Spektorofotometer UV-Vis (Shimadzu) adalah alat untuk menentukan kadar karoten. Nuclear magnetic resonance (NMR) (mqone SFC Analyzer the Minispec, Bruker) adalah alat untuk menentukan kandungan lemak padat. Kromatografi gas (GC-2010, Shimadzu) adalah alat untuk menentukan komposisi asam lemak.

\section{Formulasi Lemak Margarin}

Margarin komersial sebagai pembanding dianalisis kadar air, karoten dan lemak. Sifat fisika kimia dari lemak dianalisis meliputi komposisi asam lemak, bilangan iod, titik leleh dan kandungan lemak padat. Selanjutnya, formulasi lemak margarin dilakukan dengan mencampurkan antara RBDPO dan RPO pada rasio 97,5:2,5-85:15 seperti yang ditunjukkan pada Tabel 1. Sifat fisika dan kimia dari campuran dianalisis seperti yang dilakukan pada produk margarin komersial.

Tabel 1. Formulasi lemak untuk margarin

\begin{tabular}{cc}
\hline Formula & Rasio RBDPO:RPO \\
\hline 1 & $97,5: 2,5$ \\
2 & $95: 5$ \\
3 & $92,5: 7,5$ \\
4 & $90: 10$ \\
5 & $85: 15$ \\
\hline
\end{tabular}

\section{Analisis Sifat Fisika Kimia}

Kadar air ditentukan dengan mengacu pada metode standar AOCS Official Method Ca 2c-25 (AOCS, 1989). Kadar karoten ditentukan dengan mengacu pada metode standar MPOB Test Method p.2.6. part 2 (MPOB, 2004). Kadar lemak ditentukan dengan mengurangkan kadar air dari contoh margarin. Bilangan iod ditentukan dengan mengacu pada metode standar AOCS Official Method Cd 1-25. Titik leleh ditentukan dengan mengacu pada metode standar AOCS Official Method Cc 1-25.

Komposisi asam lemak ditentukan menggunakan alat kromatografi gas (GC-2010, Shimadzu) dengan mengacu pada metode standar AOCS Official Method Ce 1b-89. Sebanyak 0.025 gr sampel ditambahkan $1,5 \mathrm{ml} \mathrm{NaOH}$ metanolik 0,5 N. Campuran kemudian dipanaskan dalam penangas air suhu $100{ }^{\circ} \mathrm{C}$ selama 5 menit. Campuran didinginkan kemudian ditambahkan $2 \mathrm{ml} \mathrm{BF}_{3}$ metanol $(14 \% \mathrm{~b} / \mathrm{v})$ dan dipanaskan kembali pada suhu $100{ }^{\circ} \mathrm{C}$ selama 30 menit. Campuran didinginkan kemudian ditambahkan $1 \mathrm{ml}$ isooktan dan diaduk selama 1-2 menit. Campuran ditambahkan $\mathrm{NaCl}$ jenuh sebanyak $5 \mathrm{~mL}$ dan diaduk. Lapisan isooktana dipisahkan dan dipindahkan ke dalam vial lalu diinjeksikan sebanyak
$1 \mu \mathrm{l}$ ke dalam kromatografi gas. Kolom yang digunakan dalam analisis komposisi asam lemak adalah $D B-23 \mathrm{~J}$ and $W$ Scientific. Kondisi operasi kromatografi gas adalah suhu detektor $260{ }^{\circ} \mathrm{C}$, suhu injektor $260{ }^{\circ} \mathrm{C}$. Temperatur oven terprogram dengan kondisi awal $70{ }^{\circ} \mathrm{C}$, kemudian dinaikkan sebesar $20{ }^{\circ} \mathrm{C} /$ menit hingga $180{ }^{\circ} \mathrm{C}$, kemudian naik $1{ }^{\circ} \mathrm{C} /$ menit hingga $182{ }^{\circ} \mathrm{C}$, kemudian naik $10^{\circ} \mathrm{C} /$ menit hingga 220 ${ }^{\circ} \mathrm{C}$ dan ditahan selama 2 menit.

Kandungan lemak padat ditentukan menggunakan alat nuclear magnetic resonance (NMR mqone, Bruker) dengan mengacu pada metode standar AOCS Official Method Cd 16b-93 (AOCS, 1989). Sampel minyak yang telah dicairkan dimasukkan ke dalam 12 tabung untuk analisis solid fat content dengan ketinggian sampel sekitar $4 \pm 1 \mathrm{~cm}$. Sampel dipanaskan di dalam waterbath pada suhu $100{ }^{\circ} \mathrm{C}$ selama 15 menit kemudian dipindahkan ke waterbath bersuhu $60{ }^{\circ} \mathrm{C}$ selama 5 menit. Sampel dipindahkan ke waterbath suhu 0 ${ }^{\circ} \mathrm{C}$ selama $60 \pm 2$ menit. Selanjutnya setiap 2 tabung sampel dipindahkan ke waterbath dengan suhu masing-masing 10 , 20, 25, 30, 35, $40{ }^{\circ} \mathrm{C}$ selama 30-35 menit. Kandungan lemak padat setiap sampel pada masing-masing suhu diukur dengan memasukkannya ke dalam holder pada alat NMR dengan metode Non Stab AOCS method.

\section{Pembuatan Margarin Pada Skala 50 kg/Batch}

Formulasi lemak dari margarin yang mendekati produk komersial digunakan dalam optimasi pembentukan tekstur pada skala $50 \mathrm{~kg} /$ batch. Skema peralatan reaktor teksturisasi ditunjukkan pada Gambar 1. Adonan margarin yang dibuat meliputi lemak (campuran antara RBDPO dan RPO), flavor, lesitin, BHA dan BHT, air dan garam dengan rasio seperti yang ditunjukkan pada Tabel 2.

Margarin dibuat dengan mencampurkan 2 fase yang berbeda yaitu minyak dan air. Ke dalam fase minyak ditambahkan lesitin, flavor, BHA dan BHT, sedangkan fase air ditambahkan garam. Campuran pada fase minyak dipanaskan pada suhu $50{ }^{\circ} \mathrm{C}$ kemudian ditambahkan fase air lalu diaduk menggunakan motor pengaduk pada kecepatan 100 rpm selama 15 menit. Selanjutnya minyak dimasukkan ke dalam reaktor texturing kemudian didinginkan dengan variasi suhu media air pendingin pada tiga kondisi meliputi $5 \pm 2,12 \pm 2$, $20 \pm 2{ }^{\circ} \mathrm{C}$ dan waktu proses $0,30,60,90,120$ menit. Campuran diaduk dalam reaktor menggunakan motor pengaduk pada kecepatan $100 \mathrm{rpm}$. Penurunan suhu campuran pada setiap kondisi proses diukur pada rentang waktu 0, 30, 45, 60, 90 dan 120 menit. 
Tabel 2. Formula margarin

\begin{tabular}{lc}
\hline \multicolumn{1}{c}{ Bahan } & Persentasi \\
\hline Lemak (RBDPO:RPO) & 81,8 \\
Air & 15,8 \\
Garam & 2 \\
Flavor & 0,05 \\
Lesitin & 0,35 \\
BHA dan BHT & 0,01 \\
\hline
\end{tabular}

Margarin yang dihasilkan pada setiap kondisi dimasukkan ke dalam wadah gelas ukur $(50 \mathrm{ml})$ dan plastik (1 kg) kemudian di-tempering pada suhu $20^{\circ} \mathrm{C}$ selama $2 \times 24$ jam. Selanjutnya kedua wadah dipindahkan ke ruangan dengan suhu berkisar antara $28-30{ }^{\circ} \mathrm{C}$ untuk uji stabilitas penyimpanan selama 7 minggu.

Mutu produk margarin yang dihasilkan dianalisis kadar air menggunakan prosedur yang mengacu pada metode standar AOCS Official Method Ca 2c-25 (AOCS, 1989). Analisis warna dari produk pada setiap kondisi proses dilakukan secara visual. Analisis juga dilakukan terhadap stabilitas emulsi, bentuk dan tekstur produk margarin selama penyimpanan dari minggu pertama hingga minggu ke tujuh. Analisis stabilitas emulsi dilakukan dengan mengukur volume fraksi minyak terhadap $50 \mathrm{ml}$ produk margarin. Analisis tekstur dilakukan secara visual dengan menentukan bentuk (padat, semi padat, cream) dan tekstur (keras, lunak, berminyak) dari produk margarin dalam wadah plastik $1 \mathrm{~kg}$.

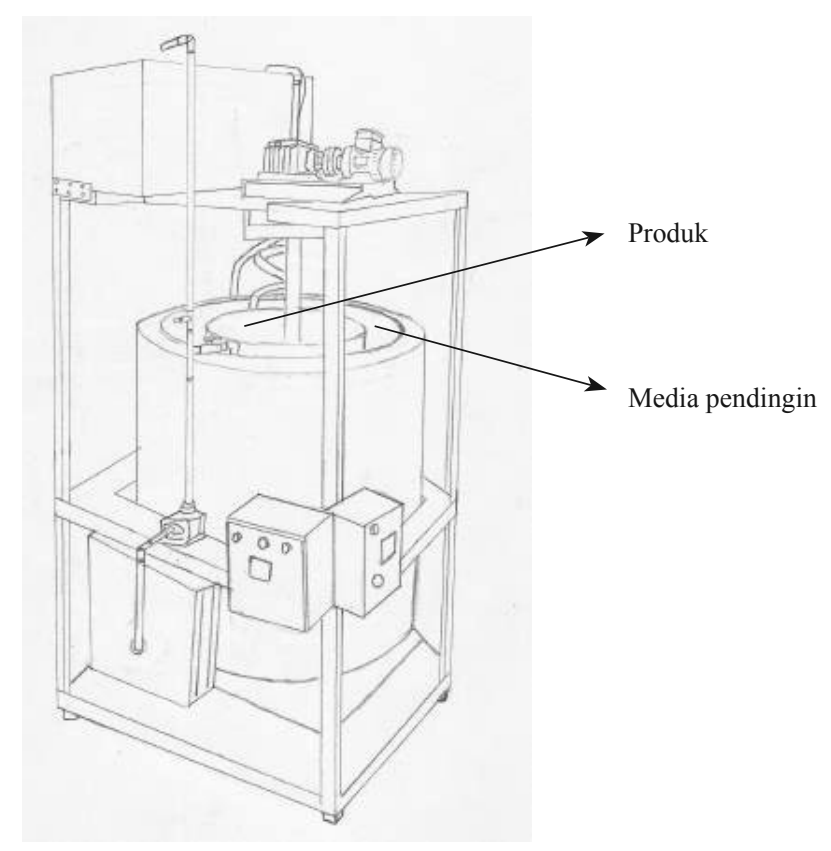

Gambar 1. Sketsa alat texturisasi skala $50 \mathrm{~kg} /$ batch

\section{Aplikasi Margarin dalam Pembuatan Bolu Gulung dan Uji Organoleptiknya}

Margarin yang memiliki tekstur dan stabilitas terbaik dari hasil optimasi kondisi proses produksi skala $50 \mathrm{~kg} /$ batch diaplikasikan dalam pembuatan bolu gulung. Formulasi dalam pembuatan bolu gulung menggunakan margarin, telur, tepung, gula, susu, vanila, dan pengemulsi sesuai formula yang dimiliki oleh Pusat Penelitian Kelapa Sawit. Bahan adonan dicampurkan hingga homogen dan dimasukkan ke dalam loyang dengan ukuran panjang $36 \mathrm{~cm}$, lebar $28 \mathrm{~cm}$ dan tinggi $3,5 \mathrm{~cm}$. Adonan yang telah rata diukur tingginya pada ke empat sisi loyang. Selanjutnya adonan dimasukkan ke dalam oven pada suhu $150{ }^{\circ} \mathrm{C}$ selama 30 menit. Setelah waktu tercapai, bolu dikeluarkan dari oven dan didinginkan kemudian diukur tingginya pada ke empat sisi loyang. Sebagai bahan pembanding digunakan margarin komersial dalam pembuatan bolu gulung.

Uji organoleptik dilakukan oleh 15 orang panelis terlatih terhadap produk bolu gulung yang menggunakan margarin hasil penelitian ini dan margarin komersial berdasarkan uji penerimaan. Panelis diminta untuk menilai berdasarkan tingkat kesukaan meliputi: rasa, tekstur, dan kenampakan. Penilaian kesukaan sesuai skala hedonik. Skor skala hedonik yang digunakan untuk rasa, tekstur dan kenampakan adalah 5 (sangat suka), 4 (suka), 3 (cukup suka), 2 ( kurang suka), dan 1 (tidak suka). Data yang diperoleh diolah secara statistik dan dilanjutkan dengan uji Duncan untuk mengetahui ada tidaknya perbedaan kedua produk (Hanafiah, 1991).

\section{HASIL DAN PEMBAHASAN}

\section{Formulasi Lemak Margarin}

Hasil uji margarin komersial diperoleh kandungan fraksi lemak sebesar 83,7\% dan fraksi air 16,3\% serta kadar karoten pada lemak sebesar 10 ppm. Tabel 3 menunjukkan bahwa margarin komersial yang digunakan sebagai pembanding merupakan jenis minyak/lemak yang telah mengalami proses hidrogenasi. Hal ini ditunjukkan dengan adanya kandungan asam lemak trans sebesar 0,4\%. Selain itu, lemak penyusunnya diduga mengandung minyak sawit yang tampak pada proporsi asam palmitat dan oleat yang mirip dengan refined bleached deodorized palm oil (RBDPO). Pada label kemasan juga tertera bahwa margarin ini mengandung minyak sawit. Menurut Hasibuan, 2012 bahwa RBDPO yang dihasilkan oleh pabrik rafinasi di Indonesia mengandung asam palmitat $(42,46-48,54 \%)$, asam stearat $(4,10-4,75 \%)$, asam oleat bentuk cis $(35,23-41,67 \%)$ dan asam linoleat (7,74-11,75\%) serta tidak mengandung asam lemak trans.

Kekhasan produk margarin adalah warnanya kekuningan yang disebabkan oleh penambahan pewarna baik 
Tabel 3. Komposisi asam lemak margarin komersial, bahan baku dan formulasinya

\begin{tabular}{|c|c|c|c|c|c|c|c|c|}
\hline $\begin{array}{c}\text { Komposisi asam } \\
\text { lemak }(\%)\end{array}$ & Komersial & RBDPO & RPO & $\begin{array}{c}\text { RBDPO:RPO } \\
97,5: 2,5 \\
\end{array}$ & $\begin{array}{c}\text { RBDPO:RPO } \\
95: 5 \\
\end{array}$ & $\begin{array}{c}\text { RBDPO:RPO } \\
92,5: 7,5\end{array}$ & $\begin{array}{c}\text { RBDPO:RPO } \\
90: 10\end{array}$ & $\begin{array}{c}\text { RBDPO:RPO } \\
85: 15 \\
\end{array}$ \\
\hline $\mathrm{C} 8: 0$ & 0,2 & 0 & 0 & 0 & 0 & 0 & 0 & 0 \\
\hline C10:0 & 0,2 & 0 & 0 & 0 & 0 & 0 & 0 & 0 \\
\hline C12:0 & 0,6 & 0,2 & 0,2 & 0,2 & 0,2 & 0,2 & 0,2 & 0,2 \\
\hline $\mathrm{C} 14: 0$ & 1,5 & 1,0 & 1,1 & 1,0 & 1,1 & 1,0 & 1,1 & 1,0 \\
\hline C16:0 & 43,2 & 44,3 & 43,8 & 43,0 & 43,9 & 43,1 & 43,5 & 43,5 \\
\hline C16:1 & 0,2 & 0,1 & 0,1 & 0,2 & 0,2 & 0,2 & 0,2 & 0,2 \\
\hline C18:0 & 4,4 & 4,3 & 4,2 & 4,3 & 4,3 & 4,3 & 4,3 & 4,3 \\
\hline C18:1 trans & 0,4 & 0 & 0 & 0 & 0 & 0 & 0 & 0 \\
\hline $\mathrm{C} 18: 1 \mathrm{cis}$ & 38,8 & 40,1 & 39,8 & 40,8 & 40,2 & 40,8 & 40,4 & 40,4 \\
\hline $\mathrm{C} 18: 2 \mathrm{cis}$ & 9,7 & 9,4 & 10,2 & 9,7 & 9,4 & 9,8 & 9,7 & 9,7 \\
\hline C18:3 & 0,2 & 0,4 & 0,4 & 0,2 & 0,2 & 0,2 & 0,2 & 0,2 \\
\hline C20:0 & 0,4 & 0,1 & 0,1 & 0,4 & 0,4 & 0,4 & 0,4 & 0,5 \\
\hline C20:1 & 0,1 & 0,1 & 0,1 & 0,2 & 0,1 & 0,1 & 0,1 & 0 \\
\hline
\end{tabular}

alami maupun sintetik yang menimbulkan warna kekuningan. Pada Tabel 4 menunjukkan bahwa lemak margarin komersial mengandung karoten sebesar $10 \mathrm{ppm}$. Menurut Rice dan Burns, 2010 bahwa minyak sawit merah (red palm oil, RPO) memiliki warna kemerahan dan mengandung sejumlah fitonutrien berupa karoten (pro-vitamin A) dan tokoferol dan tokotrienol (vitamin E), sehingga penggunaan RPO sebagai bahan campuran dapat menggantikan pewarna dan vitamin sintetik.

Tabel 4. Kadar karoten lemak margarin komersial, bahan baku dan formulasinya

\begin{tabular}{lr}
\hline \multicolumn{1}{c}{ Sampel } & Karoten $(\mathrm{ppm})$ \\
\hline Lemak pada margarin komersial & 10 \\
RBDPO & 1 \\
RPO & 252 \\
RBDPO:RPO 97,2:2,5 & 7,3 \\
RBDPO:RPO 95:5 & 13,0 \\
RBDPO:RPO 92,5:5 & 19,8 \\
RBDPO:RPO 90:10 & 26,1 \\
RBDPO:RPO 85:15 & 38,7 \\
\hline
\end{tabular}

Dari karakteristik komposisi asam lemak margarin komersial yang ditunjukkan pada Tabel 3 dilakukan pembuatan margarin dengan mencampurkan antara RBDPO dan RPO pada rasio 97,5:2,5 - 85:15. Dari hasil uji menunjukkan bahwa seluruh formula tidak memberikan perbedaan yang besar dari komposisi asam lemak (Tabel 3), bilangan iod dan titik leleh (Tabel 5), serta kandungan lemak padat (Gambar 2).
Namun peningkatan jumlah RPO pada formula menyebabkan kadar karoten meningkat (Tabel 4). Hal ini disebabkan oleh karakteristik fisika dan kimia RBDPO mirip dengan RPO

Tabel 5. Bilangan iod dan titik leleh margarin komersial dan formulasinya

\begin{tabular}{lcc}
\hline \multicolumn{1}{c}{ Sampel } & $\begin{array}{c}\text { Bilangan iod } \\
(\mathrm{Wijs})\end{array}$ & $\begin{array}{c}\text { Titik leleh } \\
\left({ }^{\circ} \mathrm{C}\right)\end{array}$ \\
\hline Komersial & 50,0 & 37,0 \\
RBDPO & 51,9 & 36,0 \\
RPO & 53,0 & 37,0 \\
RBDPO:RPO 97,5:2,5 & 52,7 & 36,0 \\
RBDPO:RPO 95:5 & 51,6 & 36,4 \\
RBDPO:RPO 92,5:7,5 & 52,8 & 36,4 \\
RBDPO:RPO 90:10 & 52,3 & 36,8 \\
RBDPO:RPO 85:15 & 52,3 & 37,0 \\
\hline
\end{tabular}

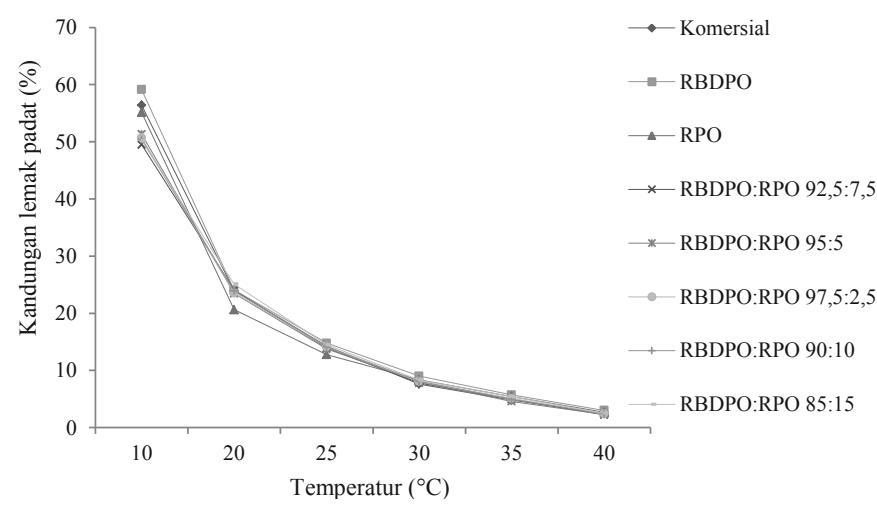

Gambar 2. Kandungan lemak padat margarin komersial dan formulasinya 
sementara yang membedakan hanya warna dan kadar karoten yang dimilikinya. RBDPO memiliki karoten sebesar 1 ppm dan berwarna kuning pucat sedangkan RPO 252 ppm dan berwarna merah. Dari formulasi yang telah dikembangkan diperoleh formula yang setara dengan produk komersial yaitu formula RBDPO:RPO pada rasio 95:5. Hal ini tampak dari komposisi asam lemak, titik leleh, bilangan iod dan kandungan lemak padatnya (Tabel 3, Tabel 5, dan Gambar 2) serta kadar karotennya sebesar 13,0 ppm.

\section{Pembuatan Margarin Skala 50 kg/batch}

Pembuatan margarin skala $50 \mathrm{~kg} /$ batch dilakukan dengan menggunakan formula RBDPO:RPO pada rasio 95:5. Margarin dibuat dengan menggunakan fraksi minyak meliputi RBDPO dan RPO, flavor, lesitin, BHA dan BHT, dan fraksi air meliputi air dan garam. Pencampuran dilakukan dengan pendinginan dan pengadukan agar terbentuk tekstur yang baik. Evaluasi pembentukan tekstur ini dilakukan dengan mengkaji penurunan suhu margarin selama proses pendinginan, kadar air, warna, oily, bentuk dan tekstur produk margarin.

\section{Penurunan Suhu Margarin Selama Proses Pendinginan}

Suhu air pendingin $5 \pm 2^{\circ} \mathrm{C}$ cenderung menurunkan suhu margarin lebih cepat dibandingkan $12 \pm 2^{\circ} \mathrm{C}$ dan $20 \pm 2^{\circ} \mathrm{C}$ (Tabel 6). Penurunan suhu margarin dari $50^{\circ} \mathrm{C}$ pada 30 menit pertama dengan suhu media pendingin $5 \pm 2,12 \pm 2$ dan $20 \pm 2^{\circ} \mathrm{C}$ masing-masing sebesar $0,6,0,5$ dan $0,4^{\circ} \mathrm{C}$ per menit. Peningkatan waktu 30 menit kedua, ketiga, keempat dan kelima menurunkan suhu margarin hanya sebesar $0,07-$ $0,13^{\circ} \mathrm{C}$ per menit. Pengecualian terjadi pada suhu $20 \pm 2^{\circ} \mathrm{C}$ dengan waktu 30 menit keempat penurunan suhu margarin sebesar $0,4^{\circ} \mathrm{C}$ per menit namun meningkatnya waktu pada 30 menit kelima menyebabkan kenaikan suhu $0,23^{\circ} \mathrm{C}$ per menit.

Tabel 6. Penurunan suhu margarin selama pendinginan

\begin{tabular}{ccccccc}
\hline & \multicolumn{6}{c}{ Suhu $\left({ }^{\circ} \mathbf{C}\right)$} \\
\cline { 2 - 7 } Waktu (menit) & \multicolumn{5}{c}{$5 \pm 2$} & \multicolumn{2}{c}{$12 \pm 2$} & \multicolumn{2}{c}{$20 \pm 2$} \\
\cline { 2 - 7 } & Air & Margarin & Air & Margarin & Air & Margarin \\
\hline 0 & 5 & 50 & 10 & 50 & 18 & 50 \\
30 & 6 & 32 & 12 & 35 & 20 & 39 \\
45 & 6 & 31 & 12 & 33 & 20 & 37 \\
60 & 6 & 29 & 12 & 32 & 20 & 36 \\
90 & 6 & 29 & 11 & 29 & 19 & 24 \\
120 & 6 & 26 & 10 & 27 & 18 & 31 \\
\hline
\end{tabular}

Dari Tabel 6 menunjukkan bahwa suhu margarin menurun dari $50^{\circ} \mathrm{C}$ menjadi $26-31^{\circ} \mathrm{C}$ selama 120 menit proses pendinginan. Menurut Czyzewski dan Greenweel (1984) bahwa proses pendinginan dalam pembentukan tekstur lemak plastis dilakukan dengan menurunkan suhu minyak dari 130$140^{\circ} \mathrm{F}\left(54,4-60^{\circ} \mathrm{C}\right)$ menjadi $70-84^{\circ} \mathrm{F}\left(21-30^{\circ} \mathrm{C}\right)$. Dengan demikian, ketiga suhu pendingin yang divariasikan ini dapat digunakan untuk pembentukan tekstur dari margarin.

\section{Kadar air}

Tabel 7. Kadar air (\%) produk margarin selama proses pendinginan

\begin{tabular}{crrr}
\hline \multirow{2}{*}{ Waktu (menit) } & \multicolumn{3}{c}{ Suhu reaktor } \\
\cline { 2 - 4 } & $5 \pm 2{ }^{\circ} \mathrm{C}$ & $12 \pm 2{ }^{\circ} \mathrm{C}$ & $20 \pm 2{ }^{\circ} \mathrm{C}$ \\
\hline 0 & 15,8 & 15,8 & 15,8 \\
30 & 15,9 & 15,8 & 15,8 \\
45 & 15,9 & 15,8 & 15,8 \\
60 & 15,8 & 15,9 & 15,8 \\
90 & 15,9 & 15,9 & 15,9 \\
120 & 16,0 & 15,9 & 15,9 \\
\hline
\end{tabular}

Air yang ditambahkan ke dalam formula margarin sebesar $15,8 \%$ dan nilai ini telah disesuaikan dengan persyaratan produk margarin sebesar 15-16\% (Hui, 1996; O'brien, 2004). Kadar air produk margarin yang dibuat pada suhu dan waktu pendinginan ditunjukkan pada Tabel 7. Pada setiap suhu dan waktu proses pendinginan memberikan kadar air yang tidak berbeda nyata. Meskipun demikian, proses pendinginan selama 120 menit menghasilkan margarin yang mengandung air sedikit lebih tinggi dibandingkan 3090 menit. Hal ini disebabkan oleh tabung tempat produk margarin kontak langsung dengan tabung media pendingin yang menyebabkan air terkondensasi ke tabung yang berisi margarin.

\section{Warna}

Tabel 8. Warna produk margarin selama proses pendinginan

\begin{tabular}{cccc}
\hline Waktu & \multicolumn{3}{c}{ Warna } \\
\cline { 2 - 4 } (menit) & $5 \pm 2{ }^{\circ} \mathrm{C}$ & $12 \pm 2{ }^{\circ} \mathrm{C}$ & $20 \pm 2{ }^{\circ} \mathrm{C}$ \\
\hline 0 & Kuning & Kuning & Kuning \\
30 & Kuning & Kuning & Kuning \\
45 & Kuning pucat & Kuning pucat & Kuning \\
60 & Kuning pucat & Kuning pucat & Kuning pucat \\
90 & Kuning pucat & Kuning pucat & Kuning pucat \\
120 & Kuning pucat & Kuning pucat & Kuning pucat \\
\hline
\end{tabular}

Margarin dari formulasi RBDPO:RPO 95:5 memberikan warna kuning namun dengan proses pendinginan terjadi perubahan warna produk (Tabel 8). Semakin rendah suhu 


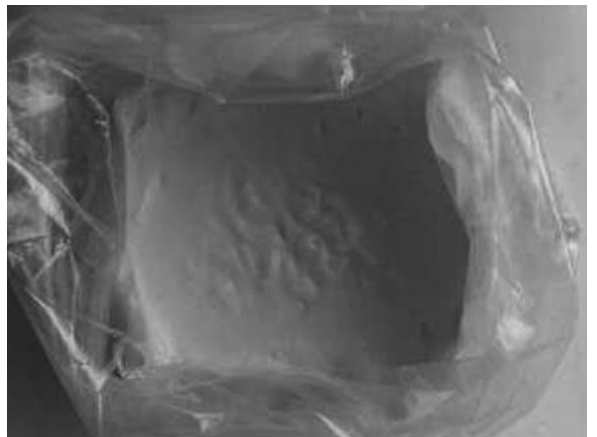

Gambar 3. Bentuk dan warna produk margarin dalam wadah plastik $1 \mathrm{~kg}$ pada kondisi proses suhu media pendingin $5 \pm 2{ }^{\circ} \mathrm{C}$ dan waktu 30 menit

dan semakin lama waktu proses pendinginan cenderung menyebabkan warna menjadi pucat. Hal ini disebabkan oleh perubahan bentuk margarin dari bentuk cair menjadi semi padat dan cream. Produk yang berbentuk cream berwarna kuning pucat.

Terjadinya bentuk cream dari produk margarin dapat disebabkan oleh beberapa faktor meliputi formulasi, laju pendinginan, proses kristalisasi dan kecepatan pengadukan. Formulasi yang digunakan pada margarin ini adalah RBDPO dan RPO pada rasio 95:5 dengan komposisi antara asam palmitat dan oleat berimbang. Pada formulasi tersebut dan laju penurunan suhu minyak per menit setelah waktu 45 menit rendah seperti yang ditunjukkan pada Tabel 6 menyebabkan terjadinya proses kristalisasi yang kurang baik. Menurut Hui (1996) bahwa minyak yang membentuk kristal yang baik dipengaruhi oleh kandungan asam palmitat, distribusi asam palmitat dan stearat pada struktur trigliseridanya, derajat hidrogenasi dan derajat randomisasi. Pada Tabel 8 dan Gambar 3 menunjukkan bahwa waktu proses 30 menit pada ketiga kondisi suhu memberikan warna produk sesuai yang diinginkan (kuning).

\section{Stabilitas Emulsi}

Hasil uji penyimpanan margarin selama 7 minggu ditunjukkan pada Tabel 9 dan Gambar 4. Produk yang dihasilkan pada suhu $5 \pm 2^{\circ} \mathrm{C}$ dengan waktu pendinginan 30-120 menit tidak menimbulkan oily hingga penyimpanan minggu ketujuh. Pada suhu $12 \pm 2^{\circ} \mathrm{C}$ dengan waktu proses pendinginan 30-90 menit juga tidak menimbulkan oily. Namun, pada waktu proses 120 menit dengan meningkatnya lama penyimpanan hingga minggu ketujuh terbentuk oily. Sementara pada suhu $20 \pm 2^{\circ} \mathrm{C}$ dengan waktu pendinginan di atas 45 menit selama 5 minggu terjadi oily dan semakin lama kadarnya semakin meningkat. Dari uji penyimpanan ini menunjukkan bahwa suhu pendinginan $5 \pm 2$ dan $12 \pm 2^{\circ} \mathrm{C}$

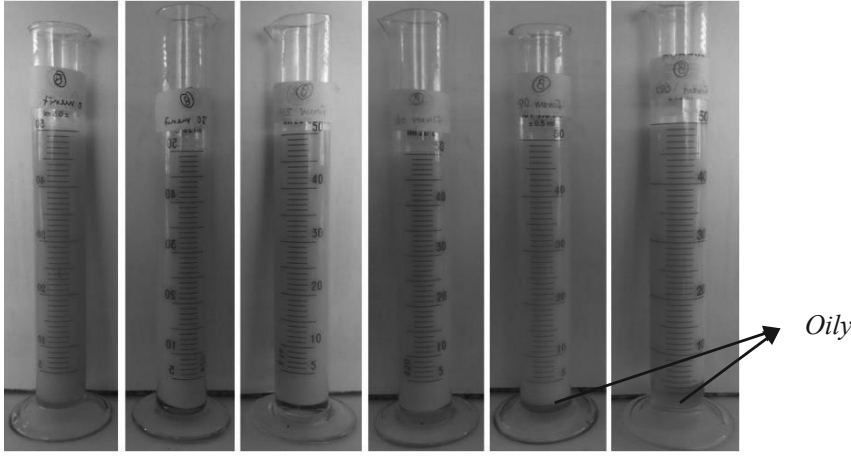

Gambar 4. Produk margarin yang tidak dan mengalami oily pada kondisi proses suhu media pendingin $20 \pm 2{ }^{\circ} \mathrm{C}$ dan waktu 60 menit

dengan waktu proses 30-60 menit relatif stabil (tidak terjadi oily) hingga penyimpanan selama 7 minggu.

Tabel 9. Kadar oily produk margarin pada variasi suhu dan waktu proses pendinginan

\begin{tabular}{|c|c|c|c|c|c|c|c|c|}
\hline \multirow{3}{*}{$\begin{array}{l}\text { Suhu } \\
\left({ }^{\circ} \mathbf{C}\right)\end{array}$} & \multirow{3}{*}{$\begin{array}{c}\text { Waktu } \\
\text { (menit) }\end{array}$} & \multicolumn{7}{|c|}{ Kadar oily $(\%)$} \\
\hline & & \multicolumn{7}{|c|}{ Lama penyimpanan (Minggu) } \\
\hline & & 1 & 2 & 3 & 4 & 5 & 6 & 7 \\
\hline \multirow{6}{*}{$5 \pm 2$} & 0 & 0 & 0 & 0 & 0 & 0 & 0 & 0 \\
\hline & 30 & 0 & 0 & 0 & 0 & 0 & 0 & 0 \\
\hline & 45 & 0 & 0 & 0 & 0 & 0 & 0 & 0 \\
\hline & 60 & 0 & 0 & 0 & 0 & 0 & 0 & 0 \\
\hline & 90 & 0 & 0 & 0 & 0 & 0 & 0 & 0 \\
\hline & 120 & 0 & 0 & 0 & 0 & 0 & 0 & 0 \\
\hline \multirow{6}{*}{$12 \pm 2$} & 0 & 0 & 0 & 0 & 0 & 0 & 0 & 0 \\
\hline & 30 & 0 & 0 & 0 & 0 & 0 & 0 & 0 \\
\hline & 45 & 0 & 0 & 0 & 0 & 0 & 0 & 0 \\
\hline & 60 & 0 & 0 & 0 & 0 & 0 & 0 & 0 \\
\hline & 90 & 0 & 0 & 0 & 0 & 0 & 0 & 0 \\
\hline & 120 & 0 & 0 & 0 & 0 & 0 & 2 & 2 \\
\hline \multirow{6}{*}{$20 \pm 2$} & 0 & 0 & 0 & 0 & 0 & 0 & 0 & 0 \\
\hline & 30 & 0 & 0 & 0 & 0 & 0 & 0 & 0 \\
\hline & 45 & 0 & 0 & 0 & 0 & 0 & 0 & 0 \\
\hline & 60 & 0 & 0 & 0 & 0 & 2 & 2 & 2 \\
\hline & 90 & 0 & 0 & 0 & 0 & 2 & 2 & 4 \\
\hline & 120 & 0 & 0 & 0 & 0 & 2 & 2 & 12 \\
\hline
\end{tabular}

\section{Bentuk dan tekstur}

Produk margarin komersial berbentuk semi padat dan teksturnya lunak. Formulasi RBDPO dan RPO pada rasio 95:5 diharapkan menyerupai produk komersial. Menurut Hasibuan dan Siahaan (2013) bahwa kedua fraksi minyak 
sawit tersebut berbentuk semi padat pada suhu ruangan. Bentuk dan tekstur produk margarin selama penyimpanan ditunjukkan pada Tabel 10. Pendinginan pada suhu $5 \pm 2,12 \pm 2$ dan $20 \pm 2{ }^{\circ} \mathrm{C}$ selama proses $30-45$ menit menghasilkan bentuk margarin semi padat dan teksturnya lunak. Namun dengan kenaikan waktu proses lebih dari 45 menit bentuknya menjadi cream dan teksturnya lunak.

Bentuk semi padat dan tekstur yang lunak relatif stabil selama penyimpanan hingga minggu ketujuh tanpa terjadinya pemisahan minyak (produk berminyak). Sementara margarin berbentuk cream dan teksturnya lunak selama penyimpanan terjadi pemisahan antara minyak dan cream (Gambar 5). Suhu pendinginan $20 \pm 2^{\circ} \mathrm{C}$ menghasilkan tekstur yang kurang baik karena dengan penyimpanan pada minggu kelima sudah terjadi pemisahan minyak dan semakin banyak jumlahnya dengan kenaikan waktu.

Dari uraian di atas menunjukkan bahwa kondisi proses pembuatan margarin pada skala $50 \mathrm{~kg} /$ batch dengan kualitas yang baik diperoleh pada suhu $5 \pm 2$ dan atau $12 \pm 2{ }^{\circ} \mathrm{C}$ selama 30 menit. Pada kondisi tersebut produk margarin yang dihasilkan memiliki kadar air dan warna yang setara dengan produk komersial, berbentuk semi padat dan teksturnya lunak serta stabil selama penyimpanan hingga minggu ketujuh.

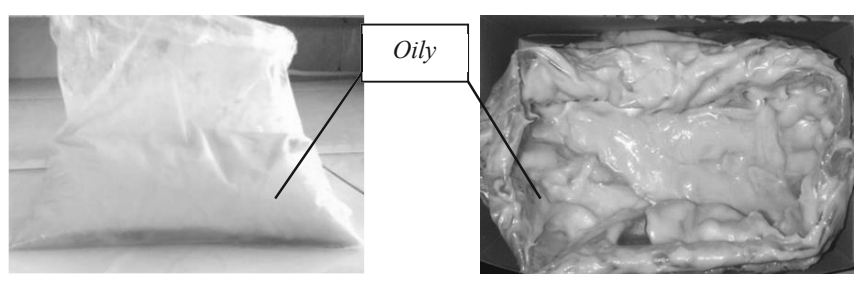

Gambar 5. Produk margarin pada kondisi proses suhu media pendingin $12 \pm 2^{\circ} \mathrm{C}$ dan waktu 120 menit berbentuk cream dan selama penyimpanan 7 minggu terpisah menjadi lapisan minyak dan cream

\section{Aplikasi Margarin dalam Pembuatan Bolu Gulung dan Uji Organoleptiknya}

Margarin yang dihasilkan dengan tekstur terbaik diaplikasikan dalam pembuatan bolu gulung. Sebagai pembanding digunakan juga margarin komersial (produk target). Hasil uji pengembangan bolu gulung ditunjukkan pada Tabel 11. Dari uji pengembangan adonan bolu menunjukkan bahwa margarin hasil penelitian ini lebih baik dengan mengembang lebih tinggi $0,2 \mathrm{~cm}$ dibandingkan margarin komersial (sebagai pembanding). Dari warna bolu gulung yang menggunakan margarin penelitian ini dan komersial tidak menunjukkan adanya perbedaan (Gambar 6).

Tabel 10. Bentuk dan tekstur margarin selama penyimpanan

\begin{tabular}{|c|c|c|c|c|c|c|c|c|c|c|c|c|c|c|c|}
\hline \multirow{3}{*}{ Suhu $\left({ }^{\circ} \mathbf{C}\right)$} & \multirow{3}{*}{ Waktu (menit) } & \multicolumn{14}{|c|}{ Lama penyimpanan (Minggu) } \\
\hline & & \multicolumn{2}{|c|}{1} & \multicolumn{2}{|c|}{2} & \multicolumn{2}{|c|}{3} & \multicolumn{2}{|c|}{4} & \multicolumn{2}{|c|}{5} & \multicolumn{2}{|c|}{6} & \multicolumn{2}{|c|}{7} \\
\hline & & Btk & Tks & Btk & Tks & Btk & Tks & Btk & Tks & Btk & Tks & Btk & Tks & Btk & Tks \\
\hline \multirow{6}{*}{$5 \pm 2$} & 0 & $\mathrm{Sp}$ & $\mathrm{L}$ & $\mathrm{Sp}$ & $\mathrm{L}$ & $\mathrm{Sp}$ & $\mathrm{L}$ & $\mathrm{Sp}$ & $\mathrm{L}$ & $\mathrm{Sp}$ & $\mathrm{L}$ & $\mathrm{Sp}$ & $\mathrm{L}$ & $\mathrm{Sp}$ & $\mathrm{L}$ \\
\hline & 30 & $\mathrm{Sp}$ & $\mathrm{L}$ & $\mathrm{Sp}$ & $\mathrm{L}$ & $\mathrm{Sp}$ & $\mathrm{L}$ & $\mathrm{Sp}$ & $\mathrm{L}$ & $\mathrm{Sp}$ & $\mathrm{L}$ & $\mathrm{Sp}$ & $\mathrm{L}$ & $\mathrm{Sp}$ & $\mathrm{L}$ \\
\hline & 45 & $\mathrm{Sp}$ & $\mathrm{L}$ & $\mathrm{Sp}$ & $\mathrm{L}$ & $\mathrm{Sp}$ & $\mathrm{L}$ & $\mathrm{Sp}$ & $\mathrm{L}$ & $\mathrm{Sp}$ & $\mathrm{L}$ & $\mathrm{Sp}$ & $\mathrm{L}$ & $\mathrm{Sp}$ & $\mathrm{L}$ \\
\hline & 60 & $\mathrm{C}$ & $\mathrm{L}$ & $\mathrm{C}$ & $\mathrm{L}$ & $\mathrm{C}$ & $\mathrm{L}$ & $\mathrm{C}$ & $\mathrm{L}$ & $\mathrm{C}$ & $\mathrm{L}$ & $\mathrm{C}$ & $\mathrm{L}$ & $\mathrm{C}$ & $\mathrm{L}$ \\
\hline & 90 & $\mathrm{C}$ & $\mathrm{L}$ & $\mathrm{C}$ & $\mathrm{L}$ & $\mathrm{C}$ & $\mathrm{L}$ & $\mathrm{C}$ & $\mathrm{L}$ & $\mathrm{C}$ & $\mathrm{L}$ & $\mathrm{C}$ & $\mathrm{L}$ & $\mathrm{C}$ & $\mathrm{L}$ \\
\hline & 120 & $\mathrm{C}$ & $\mathrm{L}$ & $\mathrm{C}$ & $\mathrm{L}$ & $\mathrm{C}$ & $\mathrm{L}$ & $\mathrm{C}$ & $\mathrm{L}$ & $\mathrm{C}$ & $\mathrm{L}$ & $\mathrm{C}$ & $\mathrm{L}$ & $\mathrm{C}$ & $\mathrm{L}$ \\
\hline \multirow{6}{*}{$12 \pm 2$} & 0 & $\mathrm{Sp}$ & $\mathrm{L}$ & $\mathrm{Sp}$ & $\mathrm{L}$ & $\mathrm{Sp}$ & $\mathrm{L}$ & $\mathrm{Sp}$ & $\mathrm{L}$ & $\mathrm{Sp}$ & $\mathrm{L}$ & $\mathrm{Sp}$ & $\mathrm{L}$ & $\mathrm{Sp}$ & $\mathrm{L}$ \\
\hline & 30 & $\mathrm{Sp}$ & $\mathrm{L}$ & $\mathrm{Sp}$ & $\mathrm{L}$ & $\mathrm{Sp}$ & $\mathrm{L}$ & $\mathrm{Sp}$ & $\mathrm{L}$ & $\mathrm{Sp}$ & $\mathrm{L}$ & $\mathrm{Sp}$ & $\mathrm{L}$ & $\mathrm{Sp}$ & $\mathrm{L}$ \\
\hline & 45 & $\mathrm{Sp}$ & $\mathrm{L}$ & $\mathrm{Sp}$ & $\mathrm{L}$ & $\mathrm{Sp}$ & $\mathrm{L}$ & $\mathrm{Sp}$ & $\mathrm{L}$ & $\mathrm{Sp}$ & $\mathrm{L}$ & $\mathrm{Sp}$ & $\mathrm{L}$ & $\mathrm{Sp}$ & $\mathrm{L}$ \\
\hline & 60 & $\mathrm{C}$ & $\mathrm{L}$ & $\mathrm{C}$ & $\mathrm{L}$ & $\mathrm{C}$ & $\mathrm{L}$ & $\mathrm{C}$ & $\mathrm{L}$ & $\mathrm{C}$ & $\mathrm{L}$ & $\mathrm{C}$ & $\mathrm{L}$ & $\mathrm{C}$ & $\mathrm{L}$ \\
\hline & 90 & $\mathrm{C}$ & $\mathrm{L}$ & $\mathrm{C}$ & $\mathrm{L}$ & $\mathrm{C}$ & $\mathrm{L}$ & $\mathrm{C}$ & $\mathrm{L}$ & $\mathrm{C}$ & $\mathrm{L}$ & $\mathrm{C}$ & $\mathrm{L}$ & $\mathrm{C}$ & $\mathrm{L}$ \\
\hline & 120 & $\mathrm{C}$ & $\mathrm{L}$ & $\mathrm{C}$ & $\mathrm{L}$ & $\mathrm{C}$ & $\mathrm{L}$ & $\mathrm{C}$ & $\mathrm{L}$ & $\mathrm{C}$ & $\mathrm{L}$ & $\mathrm{C}$ & B & $\mathrm{C}$ & B \\
\hline \multirow{6}{*}{$20 \pm 2$} & 0 & $\mathrm{Sp}$ & $\mathrm{L}$ & $\mathrm{Sp}$ & $\mathrm{L}$ & $\mathrm{Sp}$ & $\mathrm{L}$ & $\mathrm{Sp}$ & $\mathrm{L}$ & $\mathrm{Sp}$ & $\mathrm{L}$ & $\mathrm{Sp}$ & $\mathrm{L}$ & $\mathrm{Sp}$ & $\mathrm{L}$ \\
\hline & 30 & $\mathrm{Sp}$ & $\mathrm{L}$ & $\mathrm{Sp}$ & $\mathrm{L}$ & $\mathrm{Sp}$ & $\mathrm{L}$ & $\mathrm{Sp}$ & $\mathrm{L}$ & $\mathrm{Sp}$ & $\mathrm{L}$ & $\mathrm{Sp}$ & $\mathrm{L}$ & $\mathrm{Sp}$ & $\mathrm{L}$ \\
\hline & 45 & $\mathrm{Sp}$ & $\mathrm{L}$ & $\mathrm{Sp}$ & $\mathrm{L}$ & $\mathrm{Sp}$ & $\mathrm{L}$ & $\mathrm{Sp}$ & $\mathrm{L}$ & $\mathrm{Sp}$ & $\mathrm{L}$ & $\mathrm{Sp}$ & $\mathrm{L}$ & $\mathrm{Sp}$ & $\mathrm{L}$ \\
\hline & 60 & $\mathrm{C}$ & $\mathrm{L}$ & $\mathrm{C}$ & $\mathrm{L}$ & $\mathrm{C}$ & $\mathrm{L}$ & $\mathrm{C}$ & $\mathrm{L}$ & $\mathrm{C}$ & B & $\mathrm{C}$ & B & $\mathrm{C}$ & B \\
\hline & 90 & $\mathrm{C}$ & $\mathrm{L}$ & $\mathrm{C}$ & $\mathrm{L}$ & $\mathrm{C}$ & $\mathrm{L}$ & $\mathrm{C}$ & $\mathrm{L}$ & $\mathrm{C}$ & B & $\mathrm{C}$ & B & $\mathrm{C}$ & B \\
\hline & 120 & $\mathrm{C}$ & $\mathrm{L}$ & $\mathrm{C}$ & $\mathrm{L}$ & $\mathrm{C}$ & $\mathrm{L}$ & $\mathrm{C}$ & $\mathrm{L}$ & $\mathrm{C}$ & $\mathrm{B}$ & $\mathrm{C}$ & B & $\mathrm{C}$ & B \\
\hline
\end{tabular}

Keterangan: $\mathrm{Btk}=$ bentuk, $\mathrm{Tks}=$ tekstur, $\mathrm{Sp}=$ semi padat, $\mathrm{C}=$ cream, $\mathrm{L}=$ lunak, $\mathrm{B}=$ berminyak 
Tabel 11. Tinggi lapisan bolu gulung sebelum dan setelah pemanggangan

\begin{tabular}{ccccccc}
\hline \multirow{2}{*}{ Ulangan } & \multicolumn{3}{c}{ Margarin hasil penelitian ini } & \multicolumn{3}{c}{ Margarin komersial } \\
\cline { 2 - 7 } & Sebelum $(\mathrm{cm})$ & Setelah $(\mathrm{cm})$ & Pengembangan $(\mathrm{cm})$ & Sebelum $(\mathrm{cm})$ & Setelah $(\mathrm{cm})$ & Pengembangan $(\mathrm{cm})$ \\
\hline 1 & 1,1 & 2,1 & 1,0 & 0,8 & 1,2 & 0,4 \\
2 & 0,8 & 1,8 & 1,0 & 1,3 & 2,2 & 0,9 \\
3 & 0,9 & 1,8 & 0,9 & 1,3 & 2,3 & 1,0 \\
4 & 0,7 & 1,7 & 1,0 & 1,1 & 1,7 & 0,6 \\
5 & 1,0 & 1,8 & 0,8 & 0,8 & 1,5 & 0,7 \\
6 & 1,2 & 2,1 & 0,9 & 1,1 & 1,9 & 0,8 \\
Rerata & 1,0 & 1,9 & 0,9 & 1,1 & 1,8 & 0,7 \\
\hline
\end{tabular}
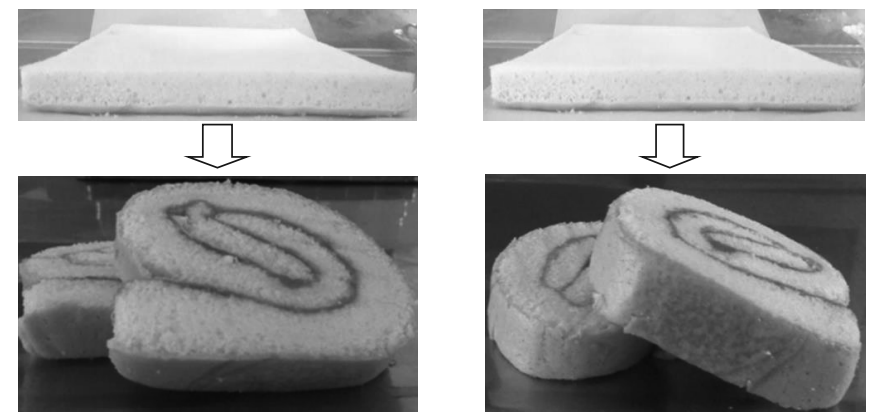

Gambar 6. Produk bolu gulung menggunakan margarin penelitian ini (kiri) dan komersial (kanan) serta contoh bolu gulung yang telah diisi selai rasa strawberry (bawah)

Hasil uji organoleptik cita rasa bolu gulung terhadap perbedaan margarin dari hasil penelitian ini dan margarin komersial ditunjukkan pada Tabel 12. Nilai rerata tingkat kesukaan terhadap tekstur berkisar antara 4,10-4,38 yang berarti panelis suka terhadap kedua produk. Bolu gulung menggunakan margarin hasil penelitian ini memiliki tekstur lebih lembut yang dibuktikan dengan nilai tinggi yang diberikan oleh panelis sebesar 4,38. Tingkat kesukaan panelis terhadap rasa menunjukkan bahwa bolu gulung menggunakan kedua jenis margarin berada pada kisaran suka (4,20-4,33). Bolu gulung menggunakan margarin penelitian ini sedikit lebih rendah $(4,20)$ dibandingkan margarin komersial karena adanya aroma yang kuat dibandingkan dengan margarin komersial. Aroma tersebut merupakan bau khas karoten yang berasal dari bahan baku RPO. Sementara margarin komersial biasanya mengandung karoten alami ataupun sintetik dalam bentuk konsentrat. Uji tingkat kesukaan panelis terhadap kenampakan berada pada kisaran suka $(4,04-4,05)$. Nilai ini berarti panelis suka dengan warna dan bentuk dari bolu gulung yang dihasilkan menggunakan kedua jenis margarin.

Hasil analisis sidik ragam terhadap tekstur, rasa dan kenampakan dari bolu gulung yang menggunakan margarin hasil penelitian ini dan margarin komersial menunjukkan nilai tidak berbeda nyata. Ini artinya panelis tidak dapat membedakan rasa bolu gulung yang menggunakan margarin komersial maupun hasil penelitian ini.

Tabel 12. Nilai rerata uji organoleptik bolu gulung terhadap rasa, tekstur dan kenampakan

\begin{tabular}{lccc}
\hline \multicolumn{1}{c}{ Bolu gulung } & Tekstur & Rasa & Kenampakan \\
\hline Margarin hasil & & & \\
penelitian ini & $4,38 \mathrm{a}$ & $4,20 \mathrm{a}$ & $4,04 \mathrm{a}$ \\
Margarin komersial & $4,10 \mathrm{a}$ & $4,33 \mathrm{a}$ & $4,05 \mathrm{a}$ \\
\hline
\end{tabular}

Keterangan: angka yang diikuti oleh huruf yang sama pada satu kolom tidak berbeda nyata pada taraf 5\% uji Duncan

\section{KESIMPULAN}

Formulasi margarin dapat dilakukan melalui pendekatan sifat fisika dan kimiawi dari produk komersial. Pada penelitian ini, pencampuran antara RBDPO dan RPO dengan rasio 95:5 dapat diperoleh formula yang mendekati margarin komersial yang mengandung minyak/lemak terhidrogenasi. Pembentukan tekstur dari formula yang setara dengan margarin komersial diuji pada skala $50 \mathrm{~kg} /$ batch dan kondisi proses yang optimum diperoleh pada suhu pendinginan $5 \pm 2$ atau $12 \pm 2^{\circ} \mathrm{C}$ selama 30 menit. Pada kondisi tersebut diperoleh produk margarin berbentuk semi padat dan tekstur lunak yang stabil selama penyimpanan 7 minggu. Aplikasinya dalam pembuatan bolu gulung menunjukkan bahwa margarin hasil penelitian ini lebih baik dengan mengembang lebih tinggi dibandingkan margarin komersial. Hasil uji organoleptik juga menunjukkan bahwa panelis tidak dapat membedakan bolu gulung yang dibuat dengan margarin hasil penelitian ini dan margarin komersial. Panelis juga menyatakan suka terhadap tekstur, rasa dan kenampakan dari bolu gulung yang menggunakan margarin hasil penelitian ini. 


\section{UCAPAN TERIMA KASIH}

Penulis mengucapkan terima kasih kepada Direktur Pusat Penelitian Kelapa Sawit yang telah memberikan dukungan pendaanaan untuk kegiatan penelitian ini melalui dana rutin penelitian Pusat Penelitian Kelapa Sawit. Penulis juga mengucapkan terima kasih kepada Warnoto, Magindrin, Deny Simanjuntak dan Ijah atas bantuannya untuk menganalisis produk di Laboratorium Oleopangan Kelti. Pengolahan hasil dan mutu sehingga penelitian dapat berjalan dengan baik.

\section{DAFTAR PUSTAKA}

AOCS (1989). Official Methods and Recommended Practices of the American Oil Chemists 'Society. $4^{\text {th }}$ edn. American Oil Chemists' Society, Champaign. IL.

Ayeleso, A.O., Oguntibeju, O.O. dan Brooks, N.L. (2012). Effects of dietary intake of red palm oil on fattty acid composition and lipid profiles in male wistar rats. African Journal of Biotechnology 11(33): 8275-8279.

Berger, K.G. dan Idris N.A. (2005). Formulation of zero-trans acid shortenings and maragarins and other food fats with products of the oil palm. Journal of the American Oil Chemists' Society 82(11): 775-780.

Butt, M.S. dan Sultan, M.T. (2009). Levels of trans fats in diets consumed in developing economies. Journal of AOAC International 92(5): 1277-1283.

Czyzewski, T.S. dan Greenwell, B.A. (1984). Process for Chilling and Plasticizing Fatty Materials. US Patent 4 439461.

Hasibuan, H.A. (2009). Plastic Fat dan Specialty Fat Berbahan Dasar Minyak Sawit dan Minyak Inti Sawit. Monograf. Pusat Penelitian Kelapa Sawit, Medan.

Hasibuan, H.A., Siahaan, D., Rivani, M. dan Panjaitan, F.R. (2009). Minyak sawit dan minyak inti sawit sebagai bahan baku formulasi plastic fat dan specialty fat. Prosiding Pertemuan Teknis Kelapa Sawit. 28-30 Mei 2009. Jakarta. Hal. 295-306.

Hasibuan, H.A. (2012). Kajian mutu dan karakteristik minyak sawit serta produk fraksinasinya. Jurnal Standardisasi 14(1): 13-21.

Hasibuan, H.A. dan Siahaan, D. (2013). Karakteristik CPO, Minyak Inti Sawit dan Fraksinya. Seri Buku Saku. Pusat Penelitian Kelapa Sawit, Medan.

Hui, Y.H. (1996). Oils and Fats in Bakery Products. In Bailey's Industrial Oil and Fats Products. $5^{\text {th }}$ edn. Vol. 3. John Willey and Sons, Inc., New York. Hal 331-336.
Jatmika, A. (1997). Formulasi margarin kaya pro-vitamin A dari minyak sawit merah. Jurnal Penelitian Kelapa Sawit 5(3): 191-204.

Larque, E., Garaulet, M., Liamas, F.P., Zamora, S. dan Tebar, F.J. (2003). Fatty acid composition and nutritional relevance of most widely consumed margarines in Spain. Grasas y Aceites 54(1): 65-70.

Lumor, S.E. dan Akoh, C.C. (2005). Enzymatic incorporation of stearic acid into a blend of palm olein and palm kernel oil: optimization by responce surface methodology. Journal of the American Oil Chemists' Society 82(6): 421-426.

MPOB (2004). MPOB Test Method: A Compendium of Test on Palm Oil Products, Palm Kernel Products, Fatty Acids, Food Related Products and Others. Malaysia.

Naz, R., Anjum, F.M., Rasool, G., Nisar, M.A., Batool, R. dan Saeed, F. (2012). Total trans fat content in commercially available hydrogenated vegetable oils. Pakistan Journal of Nutrition 11(2): 145-149.

Noraini, S. dan Teah, Y.K. (1994). Palm and palm kernel oils in margarines and other emulsion products. Dalam: Arifin, A., Basri, M.N.H., Minal, J., Jaais, M.R.M., Ghazali, R., Halim, N.A., Mazlan, M. dan Mahidin, M.R. (ed.). Selected Readings on Palm Oil and Its Use, hal. 130136. Palm Oil Research Institute of Malaysia, Malaysia.

O'Brien, R.D. (2004). Fats and Oils, Formulating and Processing for Application. Technomic Publishing Co. Inc. Lancaster. Hal. 15-42.

Ovesen, L., Leth, T. dan Hansen, K. (1996). Fatty acid composition of danish margarines and shortenings, with special emphasis on trans fatty acids. Lipids 31(9): 971975.

Rice, A.L. dan Burns, J.B. (2010). Moving from efficacy to effectiveness: red palm oil's role in preventing vitamin A deficiency. Journal of the American College of Nutrition 29(3): 302S-313S.

Sahri, M.M. dan Idris, N.A. (2010). Palm stearin as low trans hard stock for margarine. Sains Malaysiana 39(5): 821827.

Siahaan, D. dan Sinaga, A.G.S. (2014). Fatty acid profiles and trans fatty acid content of Indonesia food products in local market containing palm oil derivatives. Proceedings of International Oil Palm Conference. Bali. 17-19 June 2014.

Sughara, R., Okamoto, T., Chimi, K., Sugano, M. dan Maruyama, T. (2006). Trans fatty acid content in Japanese comercial margarines. Journal of Oleo Science 55(1): 59-64. 